\title{
Evaluation of Ponderosa Pine Seed Sources for Windbreaks in the Central Great Plains of the United States
}

\author{
Wayne A. Geyer
}

\begin{abstract}
Ponderosa pine (Pinus ponderosa Laws.) has been planted widely in the Great Plains of the United States for windbreaks. Recommendations based on a 1968 study were to use material from south central South Dakota and north central Nebraska. A second test to further delineate seed sources (provenances) in this region was established in 1986. This paper reports results for survival, height, diameter, and $\mathrm{D}^{2} \mathrm{H}$ measurements in both Kansas and South Dakota, after 15 years. Results identify a wide range of suitable geographic provenances within the two-state region. A majority of the tested sources performed well in both states, thus verifying the original recommendations.

Key Words. Growth Characteristics; Pinus ponderosa; Ponderosa Pine; Provenance; Seed Source; Tree Selection; Windbreaks.
\end{abstract}

Ponderosa pine (Pinus ponderosa Laws.) is an important component of the windbreak agroforestry system in the Great Plains (U.S.). Its drought tolerance, dense crown form, and tall growth habit make ponderosa pine excellent for windbreaks, sight barriers, and ornamental plantings (Flint 1983). It is one of the few tall trees that grow in the region and also provides full year-round protection to fields and farmsteads because of its evergreen nature (Schaefer and Baer 1985). The natural range of ponderosa pine extends from British Columbia, Canada, southward into northern Mexico, and from California eastward into the Great Plains, except for Kansas (Crichfield and Little 1966). The tree has been widely planted in the plains region but has shown inconsistent performance.

Western pine tip moth (Rhyacionia bushnelli) has caused widespread damage in the plains (Kopp et al. 1987), but outstanding performance of some individual trees in the plains plantations suggests that proper seed selection could improve tree quality.

Early studies determined that trees grown from seed collected from the northeastern range of ponderosa pine performed best in most of the provenance test plantations (Deneke and Read 1975; Baer and Collins 1979; Read 1983; Schaefer and Baer 1985; Van Haverbeke 1986; Schaefer and Baer 1992). Also, six-year data from a Kansas plantation showed that early growth appeared to be clinally related to the elevation of seed provenances (Deneke and Read 1975). Therefore, plains nurseries have focused much of their ponderosa pine production on seed collections near Ainsworth and Valentine, Nebraska, and Rosebud, South Dakota. In addition, trees from Jordan, Montana, performed well in more than half of the early plantations (Read 1983).

In 1986, a second cooperative ponderosa pine study was initiated by the GP-13 Technical Committee of the Great Plains Agricultural Council in cooperation with the North Central and Rocky Mountain Forest Experiment Stations. The intent of the study was to more intensively sample recommended provenances identified in the 1968 study to locate a wider zone of collection for commercial plant material and/or breeding activities. Collection areas are from four states. Nine tests were established in Saskatchewan, Canada; and in the United States, Montana, North Dakota, South Dakota, Nebraska, Kansas, Oklahoma, Texas, and Minnesota. This paper reports data from the South Dakota, Nebraska, and Kansas tests. No additional tree improvement studies have been initiated in the United States since this effort. Recently, a genetic tree improvement effort was initiated in Argentina (Meier et al. 2004), with intention to establish seed orchards in Patagonia. Tree improvement studies have attributed approximately $2 \%$ of the total variation to differences among geographic locations in the southwestern United States (Yow et al. 1992). One generation of tree improvement may lead to gains in yield of $1 \%-15 \%$ or reduce rotations by $1-20$ years in ponderosa pine in the Inland Empire Tree Improvement Cooperative in the northern Rockies of the United States (Hamilton and Rehfeldt 1994).

\section{MATERIALS AND METHODS}

The tree plantations reported here used seedlings representing 138 open-pollinated families from 13 geographic provenances (Figure 1; Table 1) and were planted in the field following standard provenance testing procedures. An individual tree factorial planting design with 6 to 8 replications and sized $1.3 \times$ $2.4 \mathrm{~m}$ in South Dakota, or $3.7 \times 3.7 \mathrm{~m}$ in Kansas plots. Spacing within each replication was represented by two (South Dakota) or five (Kansas) trees in single-tree, noncontiguous plots. Two border rows surrounded each plantation. Weeds were controlled by cultivation for the first three years. The Kansas plantation was near Milford Lake, and the South Dakota plantation was near Brookings, both located on alluvial sandy loam sites. 
Superior height growth potential can be accurately identified at an early age [i.e., 5 to 15 years (Lambeth 1980; Read 1983; Van Haverbeke 1986; Schaefer and Baer 1992)]. In this analysis, data were also analyzed separately for each plantation.

Analysis consisted of using the Mixed Model procedure of SAS (SAS Institute 2003) for height, trunk diameter, and $\mathrm{D}^{2} \mathrm{H}$ (a measure of trunk volume) Family $\times$ provenance was tested as a random factor. LSMEANS/Tukey multiple range test for mean separation and $\chi^{2}$ for survival, stem crook, sweep, and number of terminal buds. In addition, correlations were determined among height, diameter, $\mathrm{D}^{2} \mathrm{H}$, and latitude and longitude of each major geographic location. The 10 major geographic provenances were compared. Most of the sources were from north central Nebraska and southern South Dakota (Figure 1; Table 1).

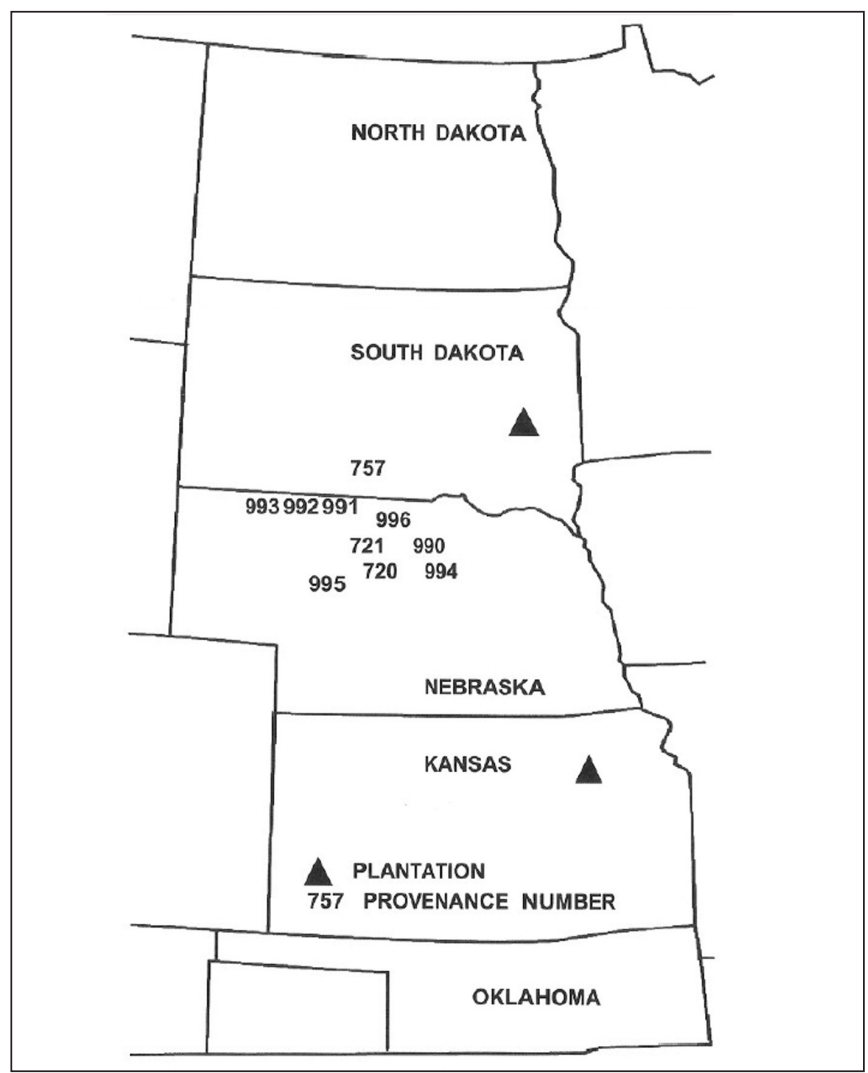

Figure 1. Collection zones (provenances) of ponderosa pine seed sources.

\section{RESULTS AND DISCUSSION}

Ten-year survival and growth were best from those materials from eastern Nebraska as reported from a greater study (Read 1983); ponderosa pine from Nebraska and South Dakota are at the extreme eastern edge of the tree's natural range. No winter dieback or diseases were detected. The top five sources for all variables were from eastern Nebraska. They came from the lower elevations (Table 1) between 710 to $800 \mathrm{~m}$.

\section{Survival}

After 15 growing seasons, survival was good for all sources (Table 2). The mean survival of all provenances was $81.9 \%$. Provenance survival ranged from $75.7 \%$ to $88.3 \%$, while Kansas was $86.4 \%$ and South Dakota was $70.7 \%$. The greater survival was from Kansas as expected as the climate is milder. The top provenances, listed in order of decreasing survival, are as follows: $721 \mathrm{NE}, 996 \mathrm{NE}, 995 \mathrm{NE}, 994 \mathrm{NE}, 990 \mathrm{NE}, 720 \mathrm{NE} . \chi^{2}$ tests indicated all provenances were significantly different at the $5 \%$ level. A similar test at age 10 showed 720 and 721 with $72 \%$ and $82 \%$ survival in the northern Great Plains in North Dakota.

\section{Diameter}

The mean diameter was $14.5 \mathrm{~cm}$, ranging from 13.2 to $16 \mathrm{~cm}$. All provenances were significantly different at the $<1 \%$ level, using the mean contrast test. The top five were the same as listed for survival, except 995NE dropped to the bottom the list and 720 rose to the fourth position, not significantly different than any of top six (Table 2).

Type 3 tests of effects are shown in Table 3 for diameter, height, and $D^{2} H$. States were significant for diameter and $D^{2} H$, but not height. Provenances were all significant at the $<0.0001 \%$ level, state $\times$ provenance interactions were significant, and the family interaction with provenance were also highly significant.

\section{Height}

The tallest provenances were in the eastern half of the collection area (Table 2). All provenances were significantly different at the $<1 \%$ level. The tallest trees listed in order of decreasing mean height are as follows: $721 \mathrm{NE}, 720 \mathrm{NE}, 990 \mathrm{NE}, 994 \mathrm{NE}$, and 996NE. The mean height was $5 \mathrm{~m}$, ranging from 4.7 to $5.8 \mathrm{~m}$. A proceeding test to the current study (Kopp 1987), using a much larger number of provenances, found 720NE, 721NE, 855NE, and $856 \mathrm{NE}$ among the tallest seedlings at four years. A provenance test in North Dakota in 1968 and 1969 (Van Deusen 1980),

Table 1. Collection zones (provenances) of ponderosa pine seed sources.

\begin{tabular}{|c|c|c|c|c|c|}
\hline $\begin{array}{l}\text { Geographic } \\
\text { provenance (\#) }\end{array}$ & $\begin{array}{l}\text { Tree - } \\
\text { families (\#) }\end{array}$ & $\begin{array}{l}\text { Local area } \\
\text { (town/state) }\end{array}$ & $\begin{array}{l}\text { Elevation } \\
(\mathrm{m})\end{array}$ & $\begin{array}{l}\text { Latitude } \\
\left({ }^{\circ} \mathrm{N}\right)\end{array}$ & $\begin{array}{l}\text { Longitude } \\
\left({ }^{\circ} \mathrm{W}\right)\end{array}$ \\
\hline 720 & 3 & Ainsworth, NE & 780 & 42.59 & 100.00 \\
\hline 721 & 4 & Valentine, NE & 800 & 42.88 & 100.55 \\
\hline 990 & 7 & Springview, NE & 740 & 42.82 & 99.75 \\
\hline 991 & 5 & Kilgore, NE & 800 & 42.94 & 100.97 \\
\hline 992 & 3 & Drinkwalter, NE & 859 & 42.47 & 101.07 \\
\hline 993 & 4 & Nenzel, NE & 950 & 42.93 & 101.11 \\
\hline 995 & 5 & Snake River, NE & 866 & 42.71 & 100.97 \\
\hline 996 & 5 & Sparks, NE & 800 & 42.94 & 100.24 \\
\hline Total & 71 & - & - & - & - \\
\hline
\end{tabular}


Table 2. Mean values for Nebraska and South Dakota, combined by provenance of the common 71 sources.

\begin{tabular}{|c|c|c|c|c|c|c|c|}
\hline \multirow{2}{*}{$\begin{array}{l}\text { Survival } \\
\text { Provenance }\end{array}$} & \multirow[b]{2}{*}{$\%$} & \multicolumn{2}{|l|}{ Diameter } & \multicolumn{2}{|l|}{ Height } & \multicolumn{2}{|c|}{$\mathrm{D}^{2} \mathrm{H}$ (volume index) } \\
\hline & & Provenance & $\mathrm{cm}$ & Provenance & $\mathrm{m}$ & Provenance & Volume \\
\hline 721 & $88.3 \mathrm{a}$ & 721 & $15.7 \mathrm{a}$ & 721 & $5.4 \mathrm{a}$ & 720 & $626 a b$ \\
\hline 996 & $88.2 \mathrm{a}$ & 990 & $15.7 \mathrm{a}$ & 720 & $5.2 \mathrm{ab}$ & 990 & $698 a$ \\
\hline 994 & $84.8 \mathrm{a}$ & 720 & $15.0 \mathrm{ab}$ & 994 & $5.1 \mathrm{~b}$ & 994 & $624 \mathrm{ab}$ \\
\hline $990^{\circ}$ & $84.4 \mathrm{a}$ & 996 & $14.7 \mathrm{ab}$ & 996 & $5.1 \mathrm{~b}$ & 996 & $626 a$ \\
\hline 991 & $83.0 \mathrm{a}$ & 992 & $14.5 \mathrm{ab}$ & 992 & $4.8 \mathrm{bc}$ & 992 & $600 \mathrm{ab}$ \\
\hline 720 & $82.9 \mathrm{a}$ & 757 & $13.7 \mathrm{~b}$ & 757 & $4.8 \mathrm{c}$ & 757 & $519 b$ \\
\hline 993 & $76.3 c$ & 991 & $13.2 \mathrm{~b}$ & 993 & $4.8 \mathrm{c}$ & 995 & $42 b$ \\
\hline 992 & $75.7 \mathrm{c}$ & 995 & $13.2 b$ & 995 & $4.7 \mathrm{c}$ & 993 & $511 \mathrm{~b}$ \\
\hline$N$ & 4194 & & 744 & & 744 & & 744 \\
\hline Mean & 81.9 & & 14.5 & & 5.0 & & 575.0 \\
\hline Sign. & $N S$ & & $<1 \%$ & & $<1 \%$ & & $<1 \%$ \\
\hline
\end{tabular}

with many of the same provenances as in this study had similar results. At ages of 5 and 10 years, the best were 721NE, 757NE, and $720 \mathrm{NE}$. Both provenances $720 \mathrm{NE}$ and $721 \mathrm{NE}$ were among the tallest in our study. Ponderosa pine from this area should maintain height growth superiority when planted in the central Plains States. Evidently these sources contain genes endowing them with a broad range of site tolerances (Read 1983). Deneke and Read 1975 found that the height of young trees was inversely related to elevation. In general, sources from lower elevations grew faster as reported by others (Mirov et al. 1952; Callaham and Hasel 1961; Squillace and Silen 1962; and Hanover 1963).

\section{$\mathrm{D}^{2} \mathrm{H}$}

The trees with the greatest size were also found to have the greatest diameter and height, and provenances were significant at the $1 \%$ level (Table 2).

Seed source (provenances) performance differed significantly ( $1 \%$ level) for all the tested variables. Although trees were not permanently marked, foregoing the opportunity to make additional collections from them, collections from geographic locations in the near vicinity would provide materials from better sources as evaluated by numerous ponderosa pine studies in the past.

\section{Other Characteristics}

Crook, sweep, form, and number of terminal buds were evaluated only for the South Dakota plantation and were not significantly different.

\section{Correlation Analysis}

There was no strong relationship between elevation, latitude, or longitude, and neither was there a relationship between survival and diameter, height or $\mathrm{D}^{2} \mathrm{H}$. Only $\mathrm{D}$ and $\mathrm{H}$ were significantly different, as well as $\mathrm{D}^{2} \mathrm{H}$ and H. Read (1983) and Schafer and Baer (1985) have found a close relationship between juvenile-mature correlations. Superior sources may be found at a fairly early age. Read (1983) noted that two- and three-year-old seedlings from the NE-SD areas are among the tallest in his nursery study.

\section{SUMMARY AND CONCLUSION}

Fast-growing trees are desirable for windbreak establishment in the Great Plains. Ponderosa pine is often planted in homestead
Table 3. Type 3 tests of effects on 15 -year-old ponderosa pine provenances.

\begin{tabular}{llrrr}
\hline Effect & \multicolumn{3}{c}{$\operatorname{Pr}>\mathrm{F}$} \\
\cline { 2 - 5 } & \multicolumn{5}{c}{ Diameter } & Height & \multicolumn{1}{c}{$\mathrm{D}^{2} \mathrm{H}$} \\
State & 1 & 0.0057 & 0.5364 & 0.0452 \\
Provenance & 9 & $<0.0001$ & $<0.0001$ & $<0.0001$ \\
State $\times$ provenance & 9 & 0.2079 & 0.0270 & 0.1084 \\
Family $\times$ provenance & 113 & $<0.0001$ & $<0.0001$ & $<0.0001$ \\
\hline
\end{tabular}

and field plantings. Plains-wide studies conducted in the 1960s showed that provenances from south central South Dakota and north central Nebraska provided better planting material. The present study was conducted to further refine selection areas for ponderosa pine sources. Materials from 10 collection areas (provenances) and 71 individual trees were planted at two Central Plains sites for evaluation. Within this relatively small area, analyses indicated that geographic provenances affected growth of 15-year-old ponderosa pine. The better sources came from eastern Nebraska, as shown in many previous studies.

The five best collection zones were from the eastern part of Nebraska (720 - Ainsworth, 721 - Valentine, 990 - Springview, 994 - Bassett, and 996 - Sparks). Growth of the top 10 individual tree sources varied within the two states. Most grew well.

\section{LITERATURE CITED}

Baer, N., and P. Collins. 1979. Ten-year performance of a ponderosa pine provenance study in eastern South Dakota. South Dakota State Univ. Agricultural Experiment Station. TB-52. 6 pp. Brookings. ND.

Callaham, R.Z., and A.A. Hasel. 1961. Pinus ponderosa height growth of wind-pollinated progenies. Silvae Genetica 10(2):32-42.

Critchfield, W.B., and E. Little, Jr. 1966. Geographic distribution of the pines of the world. USDA. Miscellaneous Publication 99. 97 pp.

Deneke, F.J., and R.A. Read. 1975. Early survival and growth of ponderosa pine provenances in East-Central Kansas. USDA Forest Service. Research Note RM-297. 4 pp.

Flint, H.L. 1983. Landscape Plants for eastern North America. John Wiley \& Sons. N.Y. 677 pp

Hamiliton, D.A., and G.E. Rehfeldt. 1994. Using individual tree growth projection models to estimate stand-level gains attributable to genetically improved stock. Forest Ecology and Management 68(2-3): 189-207. 
Hanover, J.W. 1963. Geographic variation in ponderosa pine leader growth. Forest Science 9(1):86-95.

Kopp, R.F., W.A. Geyer, and R.M. Argent. 1987. Evaluation of ponderosa pine seed sources for the eastern Great Plains. Journal of Arboriculture 13(5):139-144.

Lambeth, C.C. 1980. Juvenile-mature correlations in Pinaceae and implications or early selection. Forest Science 26:571-580.

Meier Martinez, A., V. Mondino, and L. Gallo. 2004. Criteria for the selection of plus trees of ponderosa pine (Pinus ponderosa) and Oregon pine (Pseudotsuga menziesii) for the establishment of seed orchards in the Andean Patagonia Region of Argentina. SGAPya. Forestal (33):2-9.

Mirov, N.T., J.W. Dufield, and A.R. Liddicoet. 1952. Altitudinal races of Pinus ponderosa -a 12-year progress report. Journal of Forestry 50:825-831.

Read, R. 1983. Ten-year performance of ponderosa pine provenances in the Great Plains of North America. USDA Forest Service Research Paper 250. 17 pp.

SAS Institute Inc. SAS 2002-2003. SAS/STAT User's guide. Version 9.1. Inst. Inc., Cary, NC.

Schaffer, P.R., and N.W. Baer. 1992. Stability of ponderosa pine provenance: results after 21 years in eastern South Dakota. Northern Journal of Forestry 9(3):102-107.

Schaffer, P.R., and W. Baer. 1985. Ponderosa pine provenance for windbreaks in eastern South Dakota. Journal of Forestry 2(4):105-107.

Squillace, A.E., and R.R. Silen. 1962. Racial variation in ponderosa pine. Forest Science Monograph 2. 27 pp.

Van Deusen, J.L. 1980. Ponderosa pine provenances for the northern Great Plains. USDA Forest Service. Research Paper RM-223. 8 pp.

Van Haverbeke, D. 1986. Genetic variation in ponderosa pine: a 15-year test of provenances in the Great Plains. USDA Forest Service Rocky Mountain Forest Range Experiment Station Research Paper 80526. $16 \mathrm{pp}$.

Yow, T.H., W.R. Wagner, D.E. Wommack, and G.A. Tuskan. 1992. Influence of selection for volume growth on the genetic-variability of southwestern ponderosa pine. Silvae Genetica. 1992. 41(6):326-333.
Résumé. Le pin ponderosa (Pinus ponderosa Laws.) a été largement planté dans les Grandes Plaines des États-Unis comme brise-vents. Les recommandations basées sur une étude de 1968 étaient d'employer du matériel végétal provenant de la région Centrale-Sud de l'état du Dakota du Sud et de la région Centrale-Nord de l'état du Nebraska. Un second test pour tracer la provenance des sources de semences dans cette région a été réalisé en 1986. Cet article traite des résultats à propos du taux de survie, de la hauteur, du diamètre et des mesures de diamètre au carré par rapport à la hauteur, et ce pour les états du Kansas et du Dakota du Sud 15 ans plus tard. Les résultats ont permis d'identifier un large éventail de provenances géographiques propices au sein des deux régions. Une majorité des provenances testées donnaient de bons résultats de performance dans les deux états, ce qui confirmait les recommandations initiales.

Zusammenfassung. In den weiten Ebenen der Vereinigten Staaten wurde als Windschutz großflächig die Ponderosa-Kiefer gepflanzt. Nach Empfehlungen einer Studie aus dem Jahr 1968 wurde hierbei Material aus dem Süden von Zentral-Süddakota und dem Norden von ZentralNebraska verwendet. Ein zweiter Test zur weiteren Eingrenzung von Saatgutherkünften in dieser Region wurde 1986 etabliert. Diese Studie berichtet über die Überlebensrate, Höhe, Durchmesser und BHD in Kansas und Süddakota nach 15 Jahren. Die Ergebnisse identifizieren eine große Reichweite von möglichen geographischen Herkünften innerhalb dieser Region der zwei Staaten. Eine Mehrzahl der getesteten Herkünfte gedieh hervorragend an diesen Standorten und bestätigte damit die ursprüngliche Empfehlung.

Resumen. Pino ponderosa (Pinus ponderosa Laws.) ha sido plantado ampliamente como rompevientos en las Grandes Praderas de los Estados Unidos. Las recomendaciones basadas en un estudio de 1968 fueron usar material de la región sur central de Dakota y central norte de Nebraska. Se estableció en 1986 en esta región una segunda prueba para delinear fuentes de semillas (procedencia). Este reporte presenta los resultados de supervivencia, altura, diámetro y D2H tanto en Kansas como en Dakota del Sur, después de 15 años. Los resultados identifican un amplio rango de procedencias geográficas dentro de la región de los dos estados. Una mayoría de fuentes probadas trabajaron bien en los dos estados, verificando por tanto las recomendaciones originales.

Wayne A. Geyer

Kansas State University

Horticulture/Forestry

Throckmorton Hall

Manhattan, KS 66506, U.S. 